\title{
Performance and Analysis of DC-DC Converter of Induction Motor Based on Renewable Biomass Energy
}

\author{
Marianna M. G. Shokrallah \\ Department of Electricity Technology \\ Faculty Of Industrial Education, Helwan University \\ Egypt \\ mariangirgis88@gmail.com \\ Dina M. Hafez \\ Department of Electricity Technology \\ Faculty Of Industrial Education, Helwan University \\ Egypt \\ dinan.mourad@gmail.com
}

\author{
Sayed M.Ahmed \\ Department of Electrical Engineering \\ Faculty of Engineering, Menoufia University \\ Egypt \\ eng.sayed1979@yahoo.com \\ E.E.EL-Kholy \\ Department of Electrical Engineering \\ Faculty of Engineering, Menoufia University \\ Egypt \\ eelkholy63@yahoo.com
}

\begin{abstract}
Decreased fossil fuels available in recent years and increased effect of gaseous fuels on the environment. This problem occurs because of the increased demand for electric power. This leads to search for new sources of energy to extract electric power from it without pollution. The use of biomass energy to produce electricity reduces our dependence on fossil fuels. In this paper Biomass energy has been used as a source to operate an induction motor. The field oriented controller (F.O.C) used to control in induction motor. The effect of the proposed controller algorithm is confirmed by the simulation results, which will be implemented using the MATLAB / SIMULINK environment. The proposed system was built in the laboratory and tested by the DSP-DS1104 digital control panel of the induction motor. Experimental results are consistent and coincide with simulation results.
\end{abstract}

Keywords-dc-dc converter; boost converter, inverter dc-ac; induction motor

\section{INTRODUCTION}

The energy consumed by people for different purposes in the industry in the twentieth century more than the volume of energy depleted in the history of mankind as a whole, has increased global energy consumption five times in the last fifty years and the value of investments to extract this energy multiple times as much energy used. As a result of increased reliance on liquid energy sources including oil, supply and demand increased from the early 1950 s and 1960 s to $54 \%$ of global energy demand in 1971 compared to $25 \%$ in 1945 , while solid energy was $60 \%$ To $21 \%$ in the same period. The energy problem has emerged since the early 1970s and has focused primarily on oil as the source of the equivalent of global energy consumption and the main factor behind the European and American industrial expansion. The year 1973 witnessed the decisions of petroleum, whether to reduce production or technical for Arab countries or those issued by
OPEC .This has helped to find alternative sources of petroleum .That these alternative sources, whether traditional or non-traditional were not economic under the old prices that helped keep them. And there is the use of solar energy [1] and tidal power [2] and hydropower [3] and wind energy [4] and energetic energy [5] and geothermal energy [6] and ground heat electricity [7] and sustainable biofuels [8]. To solve the energy problem. And was selected to solve the problem of energy and waste disposal by biomass energy recently, biomass represents about $14 \%$ of primary energy consumption and expected to provide $50 \%$ of world total primary energy consumption by 2050 [9].

Biomass energy is one of the most important sources of renewable energy and is obtained from organic materials either directly from plants or indirectly from the products of industrial, agricultural, domestic and commercial. Bioenergy is a balanced technique because carbon dioxide released during energy generation is balanced with the carbon dioxide absorbed by plants during their growth.

In this paper, biomass energy is used as a source for induction motor operation. The system consists of a rectifier circle, used to convert AC to DC current. The boost converter is a DC to DC power converter, it's the output voltage greater than the input voltage. The inverter is used to convert DC to AC current. The inverter is controlled by F.O.C to operate the induction motor. 


\section{SYSTEM DESCRIPTION}

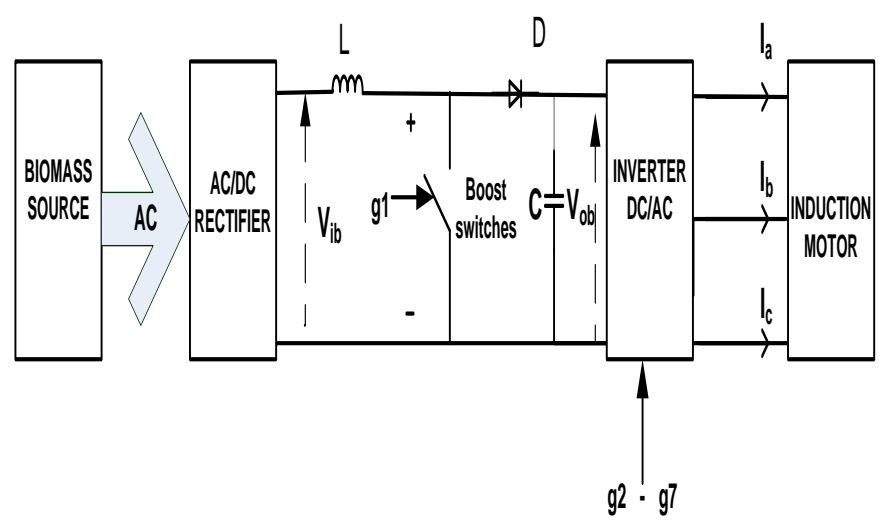

Fig. 1 block diagram of the proposed system

Figure.1 shows the block diagram of proposed system consists of main parts: the biomass energy use to feed the induction motor, AC - DC rectifier, Boost converter and DC$\mathrm{AC}$ inverter. The boost circuit is shown in Fig. 1. It has a stepup conversion and the average output can be obtained by:

$$
\frac{V_{\text {ab }}}{V_{\text {ib }}}=\frac{1}{1-k}
$$

Where $\mathrm{V}_{\mathrm{ib}}$ is the input voltage of the boost converter, $\mathrm{V}_{\mathrm{ob}}$ is the output of the converter, and $\mathrm{K}$ is the duty cycle.

The converter is consists of a coil, capacitor, diode and one switch. An inverter circuit is constructed by six switches. Its function is to convert the DC power from the boost converter into AC power. The output inverter is used to operate and control three phase Induction motor [10]. The Field Oriented controller [11] is used in the proposed system. Fig. (2) Gives the current controllers as a part of a complete drive system, hence a short description of the so called rotor field oriented control (RFOC) will be given [12]. The main idea behind FOC is to divide the stator current of the induction motor into a flux producing part isd and a torque producing part isq [13][14]. By controlling these two components independently a good dynamic behavior can be obtained depending on the type of the used current controller [15]. In order to meet the requirement of RFOC, the rotor flux should be aligned to the $\mathrm{d}$-axis and the following relationship can be obtained [16].

$$
\lambda_{\mathrm{dr}}^{\mathrm{e}}=\mathrm{i}^{\mathrm{e}} \mathrm{ds}\left(\frac{\mathrm{Lm}}{1+\mathrm{T}_{\mathrm{r}} * \mathrm{P}}\right)
$$

And the q-axis stator current is

$$
\mathrm{i}_{\mathrm{qs}}^{\mathrm{e}}=\omega_{\mathrm{s}} \lambda_{\mathrm{dr}}^{\mathrm{e}} \frac{\mathrm{Tr}}{\mathrm{Lm}}
$$

Then, the motor torque becomes

$$
\mathrm{T}_{\mathrm{e}}=\frac{3}{2} \mathrm{P} \frac{\mathrm{Lm}}{\mathrm{Lr}}\left(\lambda_{\mathrm{dr}}^{\mathrm{e}} \mathrm{i}_{\mathrm{qs}}^{\mathrm{e}}\right)
$$

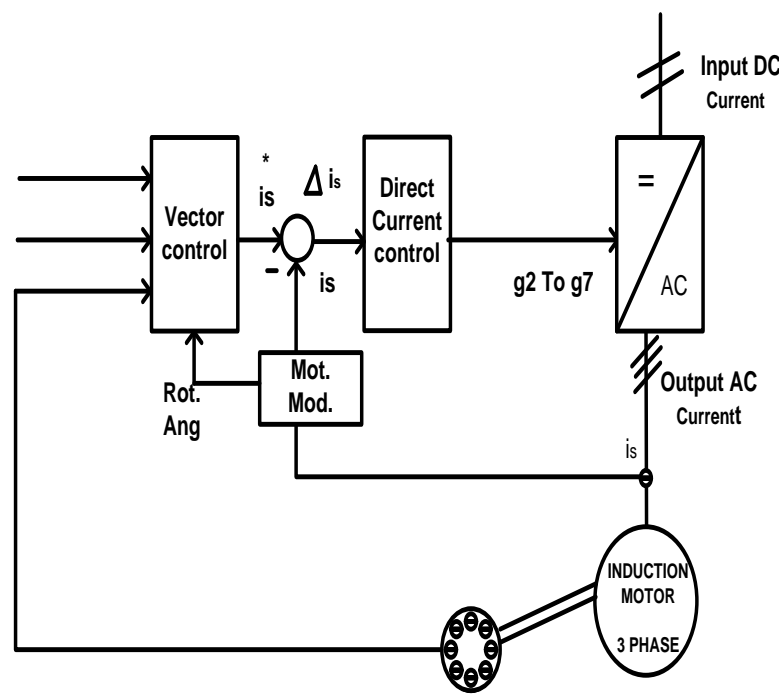

Fig. 2 Direct current controlled induction motor drive

\section{SimUlation RESULTS}

The simulation result of the proposed system is taken away using MATLAB software. And the parameters of induction motor are as follows: $\mathrm{Ls}=.4335 \mathrm{H}, \mathrm{Lr}=.4335 \mathrm{H}, \mathrm{Lm}=.411 \mathrm{H}$, $\mathrm{Rs}=7.4826 \Omega, \mathrm{Rr}=3.834 \Omega, \mathrm{P}=2, \mathrm{WE}=100 \mathrm{rad} / \mathrm{s}, \mathrm{j}=.01$.

The steady state simulation results are shown In Figure 3. Figure 3.a shows the three-phase stator current waveforms of the motor. The three phases of the stator current are symmetrical and have shape sine waves. Fig.3.b shows the load torque of the motor. The load torque is constant at 3.5 N.m. Fig.3.c shows the speed of the induction motor.

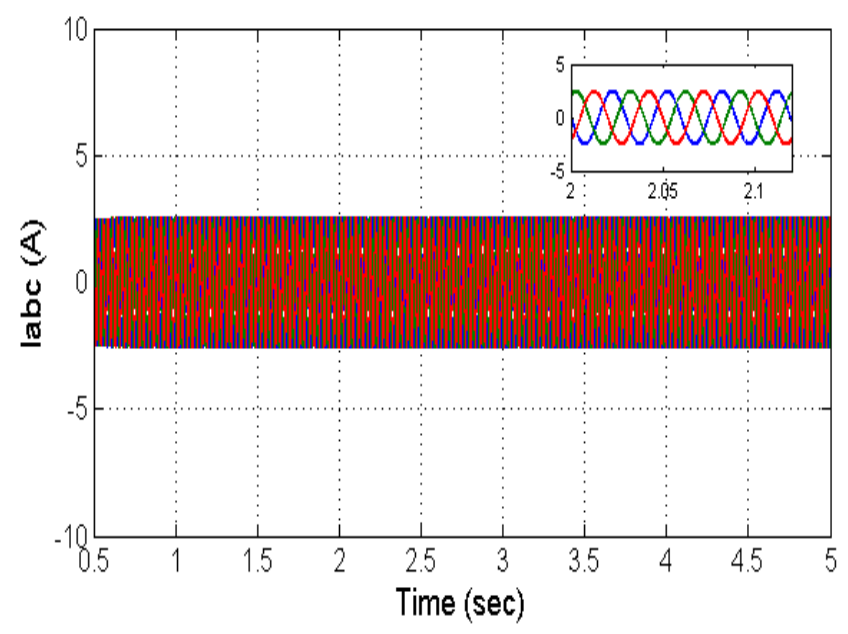

(a) 
International Journal of Applied Energy Systems, Vol. 2, No. 1, Jan 2020

ISSN: 2636 - 3712 (Printed Version) ISSN: 2636 - 3720 (Online Version) Special Issue: ICEE-2019

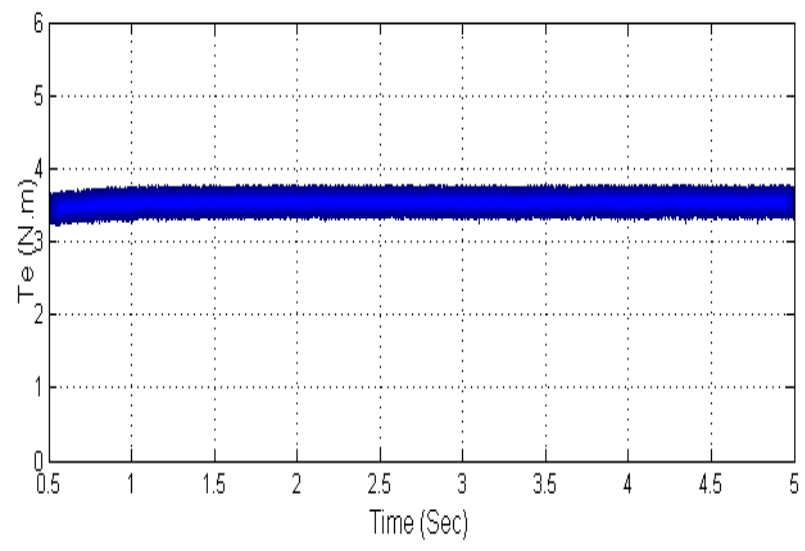

(b)

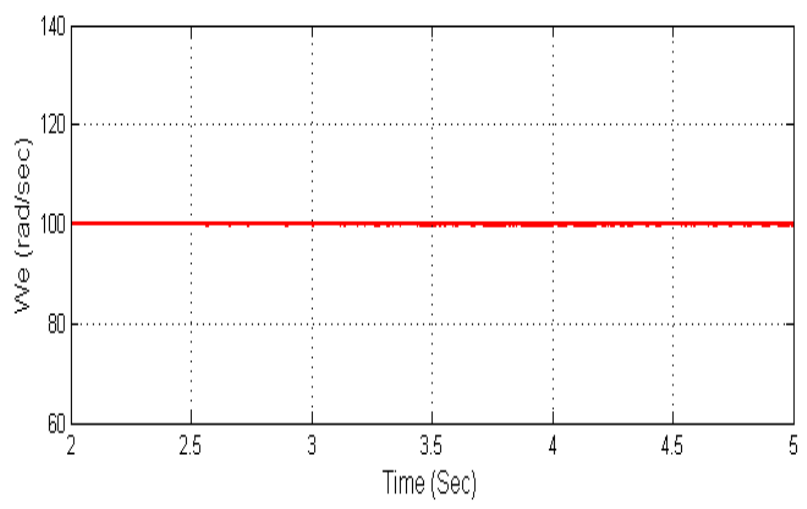

(c)

Fig.3. the steady state simulation results; a). Three phase currents; b). Load torque at $3.5 \mathrm{Nm}$; c). The speed is at $100 \mathrm{rad} / \mathrm{sec}$

Transient results are shown in Figure 4 .Figure 4(a) shows the change in three-phase currents due to the change in load torque. Fig.4.b shows the increase the load torque from $3.5 \mathrm{Nm}$ to 7 $\mathrm{Nm}$ at time 2sec. Fig.4.c shows the speed of the induction motor in this case.

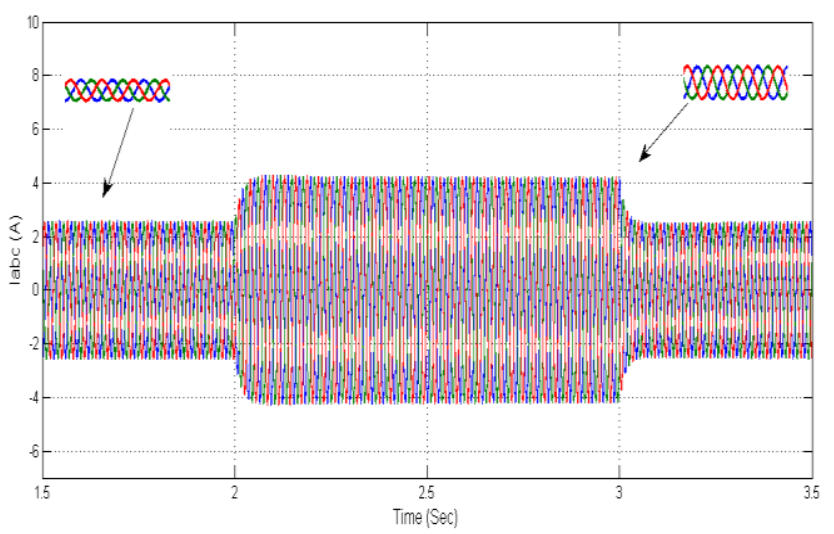

(a)

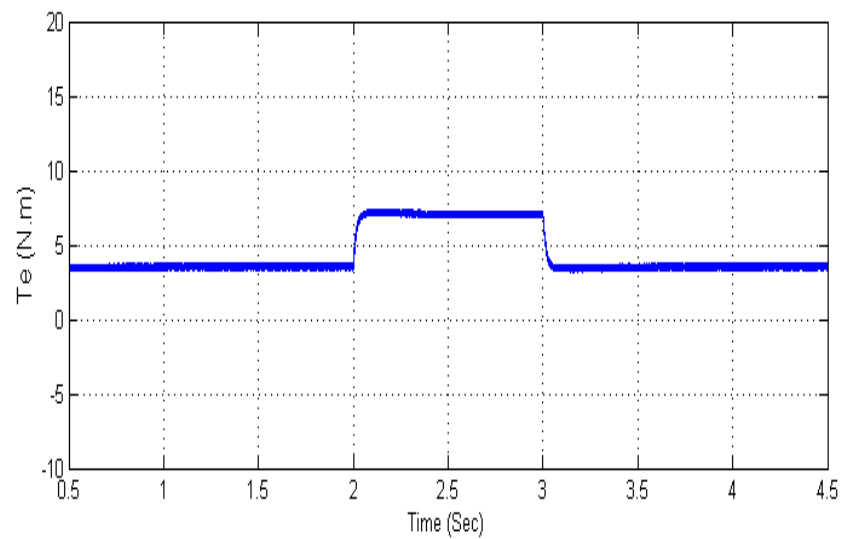

(b)

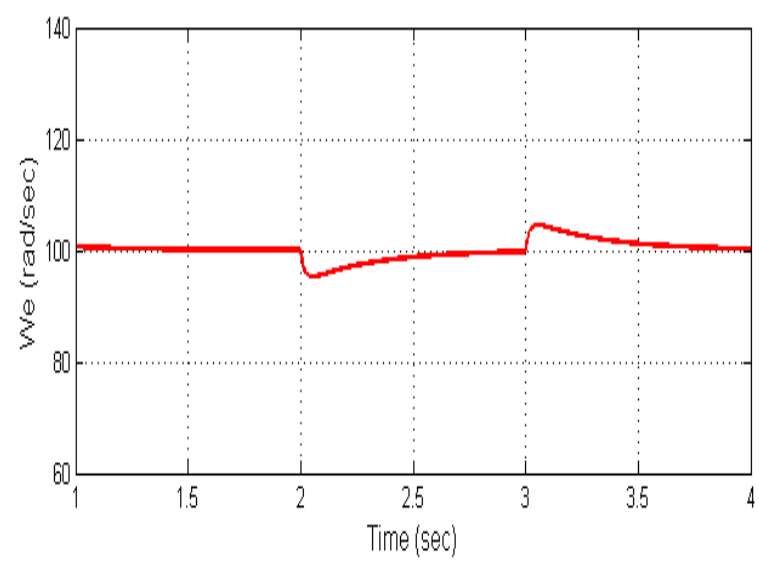

(c)

Fig.4. the transient state simulation results (when load torque is changed 3.5 to 7 ); a) three phase currents. ; b) Load torque at 3.5 to $7 \mathrm{Nm}$; c) the speed of induction motor

\section{EXPERIMENTAL RESUlts}

With the objective of evaluating the employed topology, a laboratory prototype is setup. The block diagram of the experimental setup and a real view of the control system are shown in Fig.5 and Fig.6, respectively. This is based on 32-bit floating point DSP TMS32OC3I as shown in Fig. 5. All the schemes in the biomass energy use to feed the induction motor illustrated in Fig.1 are realized digitally using a DSP board DS-1104, which is based on 32-bit floating point DSP TMS32OC3I as shown in Fig.5. The board is also integrated with a fixed point 16 bit TMS320P14 DSP, which is used as a slave processor as shown in Fig.5. This DSP board-based system is used to experimentally evaluate the control technique. The board is also integrated with a fixed point 16 bit TMS320P14 DSP, which is used as a slave processor as shown in Fig.5. The system includes anti-aliasing filter before the A/D converter where the anti-aliasing filter has a cut-off frequency equal to or less than the Nyquest frequency. This filter eliminates any frequency greater than the Nyquest frequency including the noise impact. The parameters of the 
converter are given in the appendix. The DSP board has facilitates to capture the experimental waveforms and exports them numerically per sample.

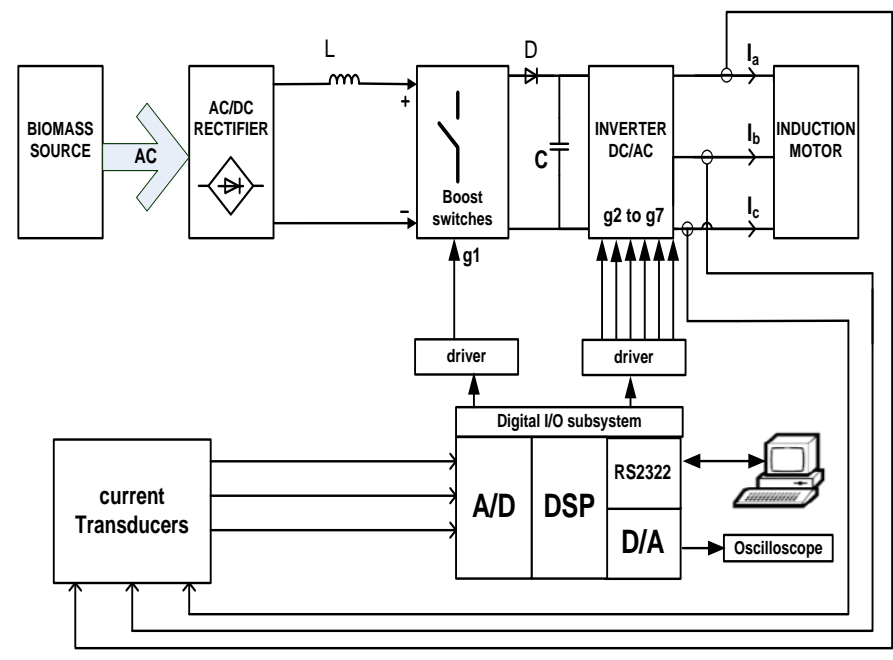

Fig. 5 Block diagram of the experimental setup

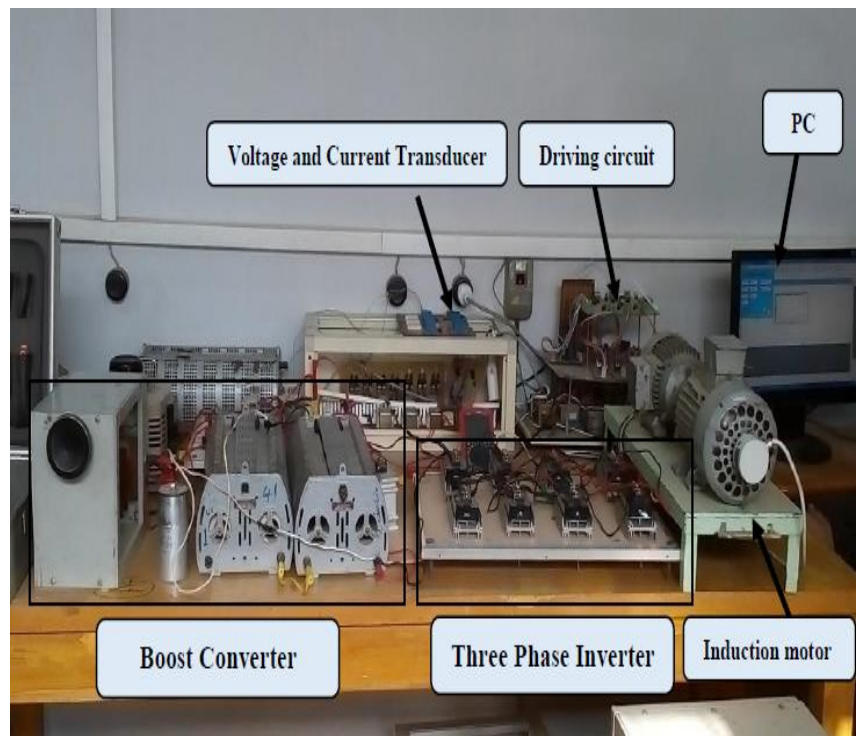

Fig. 6 Experimental setup of the proposed circuit.

Figure 7 shows the steady-state experimental results of the proposed circuit. The three phase currents have been shown to have approximately a sine wave shape as shown in the figure 7(a). Fig.7. b show the waveforms of the three phase load currents with change the torque.

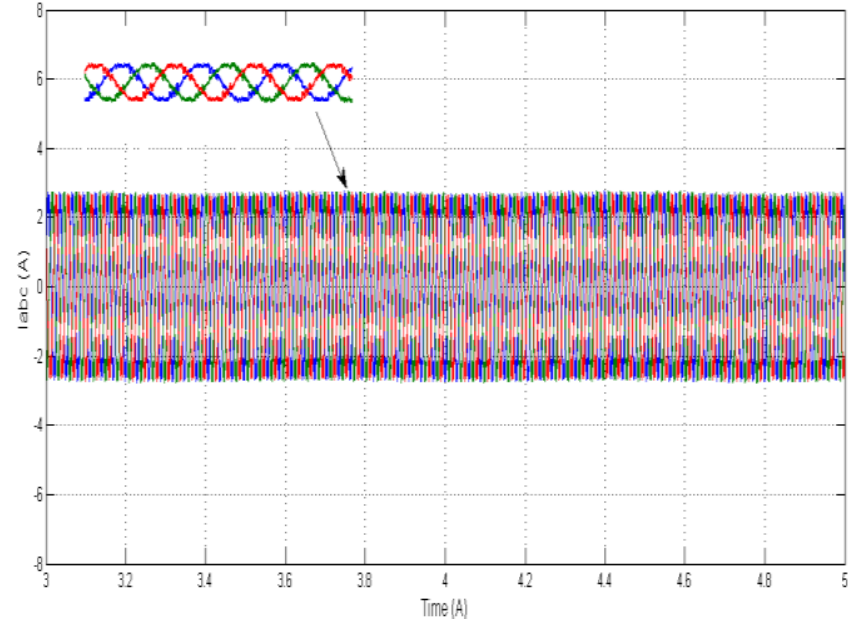

(a)

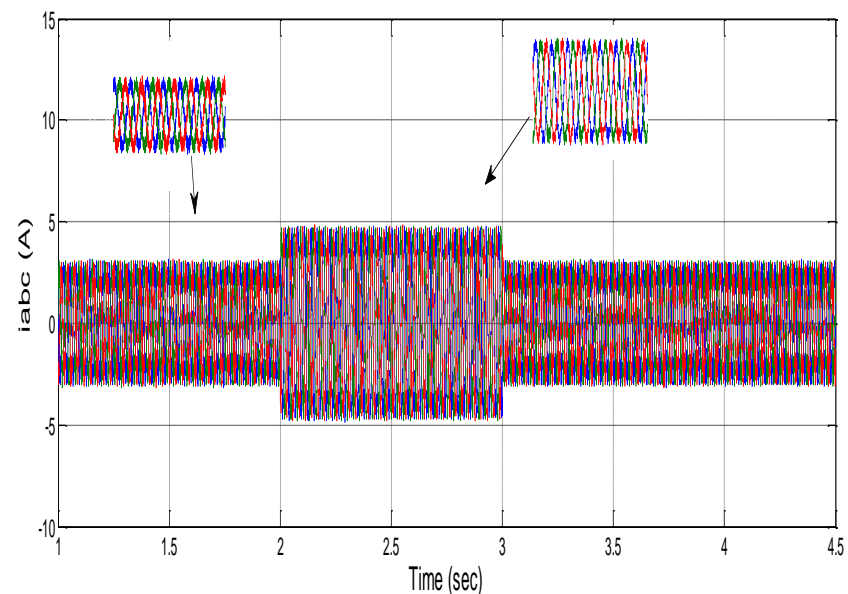

(b)

Fig.7 the transient experimental results; a) Three phase currents (at constant torque); b) Three phase currents (when load torque is changed). .

\section{CONCLUSIONS}

The paper presents the use of biomass energy to feed an induction motor and control its speed by F.O.C. MATLAB simulations using calculated parameters were performed and corresponding waveforms were obtained. All of the specifications stated previously have been met, Based on the rotor field oriented control (FOC) of 3phase induction motor, The simulation results show that the FOC system can smoothly work and still has prefect static and dynamic characteristics under normal working condition. This system is valid for the induction motor as it cleared in simulation and experimental results. The proposed system has been built and tested in the laboratory using DSP-DS1104 digital board. 


\section{REFERENCES}

[1] AYODELE, O., OGUNLANAA, A. O., GORYUNOVA, N. N., (2016). Tax Incentives for Renewable Energy: The European Experience, WELLSO 2016 - III International Scientific Symposium on Lifelong Wellbeing in the World,

[2] US DOE. 2010. Energy efficiency and renewable energy marine and hydrokinetic database. Energy Efficiency and Renewable Energy, US Department of Energy, Washington, DC, USA.

[3] Egypt pulls out of regional power pool as it protests use of. The East African Available at: http://www.theeastafrican.co.ke/news/Egypt-pullsout-of-power-pool-as-it-protests-use-of-Nile-waters/2558-3065704x4qbu2z/index.html, (2016)

[4] T.W. Brown, T. Bischof-Niemz, K.Blok, C. Breyer,H. Lund, B.V. Mathiesen, Response to 'Burden of proof: a comprehensive review of the feasibility of $100 \%$ renewable-electricity systems', Renew. Sustain. $\begin{array}{lllll}\text { Energy } & \text { Rev. } & 92 & \text { (2018) } & \text { 834-847 }\end{array}$ https://doi.org/10.1016/j.rser.2018.04.113.

[5] Heberle, F.; Eller, T.; Brüggemann, D. Thermoeconomic evaluation of one-and double-stage ORC for geothermal combined heat and power production. In Proceedings of the European Geothermal Congress 2016, Strasbourg, France, 19-23 September 2016.

[6] Kuyumcu O C, Serin O, Ozalivli C C, et al. Design and Implementation of the geothermal hybrid geothermal and solar thermal power system[A]. Geothermal Resources Council[C], Portland, Oregon, USA, 2014

[7] Simms, R. B., Haslam, S. R., and Craig, J. R., 2014, "Impact of Soil Heteroge- neity on the Functioning of Horizontal Ground Heat Exchangers," Geothermics, 50, pp. 35-43.
[8] "Biomass to Renewable Energy Processes "Doctoral Jay J. Cheng, Environmental Engineering ,University of Cincinnati ,Cincinnati,United States of America,5,October 2017

[9] Advances in Renewable Energies and Power Technologies"Doctoral Imene Yahyaoui ,Systems and Process Engineering,University of Valladolid,Valladolid, Spain,23,February 2018.

[10] K. Kyun, M. Ho Shin, D. S. Hyun " Direct Torque Control Of Induction Motor with Reduction of Torque Ripple," in Conference Record IEEEIECON 2000

[11] I. Takahashi, T.Noguchi," A new quick response and high efficiency control stratigies of an induction motor", IEEE Tran. Ind. App., Vol. IA. 22, pp. 820-827, 1986.

[12] R. Kennel, A. El-Refaei, F. Alkhady, S. Mahmoud, E. Elkholy, "Improved Direct Torque Control for Induction Motor Drives with Rapid Prototype System", IEEE-IECON 2003, November 2003, Roanoke.

[13] T. Noguchi, M. Yamamoto, S. Kondo and I. Takahashi, "Enlarging Switching Frequency in Direct Torque Controlled Inverter by Means of Dithering" IEEE Trans. Ind. Appl., Vol. 35, No. 6, pp. 1045-1053, Nov./Dec. 1999.

[14] J. K. Kang and S.K.Sul, "New Direct Torque Control of Induction Motor for Minimum Torque Ripple and Constant Switching Frequency," IEEE Tran. Ind. App., Vol. 35, No. 5, pp. 1076-1082, Sept./Oct.1999.

[15] Vitor Femao Pires, Jose Fernando A. Silva, Teaching Nonlinear Modeling, Simulation, and Control of Electronic Power Converters Using MATLAB/SIMULINK, IEEE Transactions on Education, vol. 45, no. 3, August 2002

[16] J.Mahdavi, A.Emadi, H.A.Toliyat, Application of State Space Averaging Method to Sliding Mode Control of PWM DC/DC Converters, IEEE Industry Applications Society October 1997. M. Young, The Technical Writer's Handbook. Mill Valley, CA: University Science, 1989. 